FUTUREPROOF 


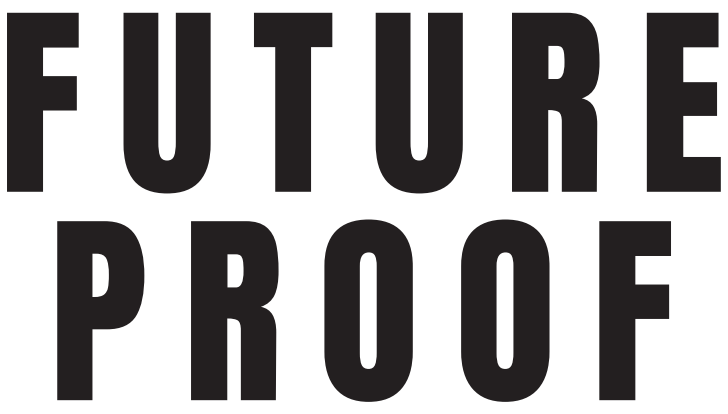

HOW TO BUILD RESILIENCE

IN AN UNCERTAIN WORLD

\section{JON CDAFFEE}

YALE UNIVERSITY PRESS

NEW HAVEN AND LONDON 
Copyright (c) 2019 Jon Coaffee

All rights reserved. This book may not be reproduced in whole or in part, in any form (beyond that copying permitted by Sections 107 and 108 of the U.S. Copyright Law and except by reviewers for the public press) without written permission from the publishers.

For information about this and other Yale University Press publications, please contact: U.S. Office: sales.press@yale.edu yalebooks.com

Europe Office: sales@yaleup.co.uk yalebooks.co.uk

Set in Minion Pro by IDSUK (DataConnection) Ltd

Printed in Great Britain by Gomer Press Ltd, Llandysul, Ceredigion, Wales

Library of Congress Control Number: 2019941048

ISBN 978-0-300-22867-0

A catalogue record for this book is available from the British Library.

10987654321 
For Maggie 
